\title{
A novel spontaneous mutation of Irs1 in mice results in hyperinsulinemia, reduced growth, low bone mass and impaired adipogenesis
}

\author{
Victoria E DeMambro, Masanobu Kawai ${ }^{1}$, Thomas L Clemens ${ }^{2}$, Keertik Fulzele ${ }^{3}$, Jane A Maynard, \\ Caralina Marín de Evsikova, Kenneth R Johnson, Ernesto Canalis ${ }^{4}$, Wesley G Beamer, Clifford J Rosen ${ }^{1}$ \\ and Leah Rae Donahue
}

The Jackson Laboratory, 600 Main Street, Bar Harbor, Maine 04609, USA

${ }^{1}$ Medical Center Research Institute, Scarborough, Maine 04074, USA

${ }^{2}$ John Hopkins University, Baltimore, Maryland 21287, USA

${ }^{3}$ Massachusetts General Hospital, Boston, Massachusetts 02114, USA

${ }^{4}$ Department of Research, Saint Francis Hospital and Medical Center, Hartford, Connecticut 06105, USA

(Correspondence should be addressed to V E DeMambro; Email: victoria.demambro@yahoo.com)

\begin{abstract}
A spontaneous mouse mutant, designated 'small' $(s m l)$, was recognized by reduced body size suggesting a defect in the IGF1/GH axis. The mutation was mapped to the chromosome 1 region containing Irs 1 , a viable candidate gene whose sequence revealed a single nucleotide deletion resulting in a premature stop codon. Despite normal mRNA levels in mutant and control littermate livers, western blot analysis revealed no detectable protein in mutant liver lysates. When compared with the control littermates, $\operatorname{Irs} 1^{\text {sml }} / \operatorname{Irs} 1^{\text {sml }}$ $\left(\operatorname{Irs} 1^{\mathrm{sml} / s m l}\right)$ mice were small, lean, hearing impaired; had 20\% less serum IGF1; were hyperinsulinemic; and were mildly insulin resistant. Irs $1^{\text {sml } / \text { sml }}$ mice had low bone mineral density, reduced trabecular and cortical thicknesses, and low bone formation rates, while osteoblast and osteoclast numbers were increased in the females but not different in the males
\end{abstract}

compared with the Irs $1^{+/+}$controls. In vitro, Irs $1^{\text {sml } / \text { sml }}$ bone marrow stromal cell cultures showed decreased alkaline phosphatase-positive colony forming units (pre-osteoblasts; CFU-AP+) and normal numbers of tartrate-resistant acid phosphatase-positive osteoclasts. Irs $1^{\text {sml } / s m l}$ stromal cells treated with IGF1 exhibited a 50\% decrease in AKT phosphorylation, indicative of defective downstream signaling. Similarities between engineered knockouts and the spontaneous mutation of Irs $1^{s m l}$ were identified as well as significant differences with respect to heterozygosity and gender. In sum, we have identified a spontaneous mutation in the Irs 1 gene associated with a major skeletal phenotype. Changes in the heterozygous Irs $1^{+/ s m l}$ mice raise the possibility that similar mutations in humans are associated with short stature or osteoporosis.

Journal of Endocrinology (2010) 204, 241-253

\section{Introduction}

Insulin and insulin-like growth factor 1 (IGF1) are critical regulators of growth and metabolism in virtually all mammals. Insulin deficiency syndromes, such as diabetes mellitus type 1 (type I DM) and low IGF1 levels from GH deficiency or resistance, are associated with reduced bone mineral density (BMD) and heightened fracture risk (Garnero et al. 2000, Janghorbani et al. 2006, 2007, Räkel et al. 2008). GH deficiency and hence IGF1 deficiency in children and adults impair peak bone acquisition and are associated with an increased prevalence of fractures in adulthood (Vestergaard et al. 2002, Mukherjee et al. 2004, Giustina et al. 2008). Similarly, a spontaneous recessive mutation in GHRH also results in low areal BMD (aBMD) in mice and humans (Donahue \& Beamer 1993, Godfrey et al. 1993, Maheshwari et al. 1998, Baumann 1999). Studies using genetically engineered mice have reinforced the importance of the IGF1 regulatory system in skeletal development. For example, global Igf1 gene deletion causes a dramatic skeletal phenotype characterized by impaired bone formation and bone resorption (Liu et al. 1993, Bikle et al. 2001, He et al. 2006, Wang et al. 2006). Conditional targeted deletion of the type I IGF receptor (Igf1r) in osteoblasts causes a profound reduction in trabecular bone volume and osteoblast function, and changes in mineralization lag time (Zhang et al. 2002). Furthermore, engineered knockout and transgenic overexpression of several IGF-binding proteins induce marked changes in bone turnover and bone mass (Silha et al. 2003, Zhang et al. 2003, Atti et al. 2005, Ben Lagha et al. 2006, DeMambro et al. 2008). Likewise, hepatic-specific deletion of Igf1 (Yakar et al. 1999) or global deletion of the acid-labile 
subunit (Igfals) in mice promotes marked thinning of the cortical bone compartment, despite minimal changes in linear growth (Yakar et al. 2009). Hence, skeletal and circulating IGF1 are essential for optimal peak bone acquisition.

Insulin and IGF1 initiate a chain of intracellular responses and signaling cascades upon binding to tyrosine kinase receptors (IR and $I g f 1 r$ ). The first substrates phosphorylated after ligand binding are the insulin receptor substrate (IRS) proteins. Once phosphorylated by their cognate receptors, these substrates bind to proteins containing Src homology-2 domains, which in turn activate a variety of signaling pathways, including activation of phosphatidylinositol 3-kinase and mitogen-activated protein kinase (Lienhard 1994, White 2003, Niu \& Rosen 2005). These intracellular signaling pathways are essential for bone acquisition, since they impact the recruitment, differentiation, and death of osteoblasts (Cornish et al. 1996, Niu \& Rosen 2005). Deletion of Irs 1 (either the Irs $1^{\text {tm1Tka }}$ or the Irs $1^{\text {tm 1Jos }}$ allele) on a mixed B6/CBA hybrid mouse background results in growth retardation; however, both female and male mice are relatively healthy and fertile (Araki et al. 1994, Tamemoto et al. 1994). Adult Irs $1^{\text {tm } 1 \text { Tka }} / \operatorname{Irs} 1^{\text {tm1 } 1 \text { Tka }}\left(\operatorname{Irs} 1^{\text {tm } 1 \text { Tka/tm1Tka }}\right)$ mice have low aBMD and delayed fracture healing, with reductions in osteoblast and osteoclast numbers and function, resulting in decreased bone turnover. These null mice also exhibit impaired anabolic response to intermittent parathyroid hormone administration (Ogata et al. 2000, Hoshi et al. 2004, Shimoaka et al. 2004, Yamaguchi et al. 2005). Both the $\operatorname{Irs} 1^{\text {tm } 1 \text { Tka/tm 1Tka }}$ and the Irs $1^{\text {tm } 1 \text { IJos }} / \operatorname{Irs} 1^{\text {tm } 1 \text { Jos }}$ (Irs $1^{\text {tm } 1 \text { Jos/tm 1Jos }}$ ) mice have high serum insulin levels and are insulin resistant despite a lean phenotype, but circulating IGF1 levels were reported not to differ significantly from those of the controls (Araki et al. 1994, Tamemoto et al. 1994, Shirakami et al. 2002). Thus, several animal models have confirmed that insulin and IGF1 signaling are critical for skeletal acquisition and maintenance.

There are no reports of a spontaneous mutation in the Irs 1 gene leading to complete loss of function in mice or in humans. However, there are numerous studies on humans demonstrating polymorphisms in the Irs 1 gene associated with metabolic disease, some of which induce amino acid changes and variable responsiveness to insulin and/or IGF1 signaling (Imai et al. 1994, Ura et al. 1996, Le Fur et al. 2002). The most common polymorphism, the G972R variant, has been associated with type II diabetes mellitus (Almind et al. 1993, Sesti 2000, Tok et al. 2006). In contrast, there is no data examining the relationship between these polymorphisms and BMD or fracture risk.

Recently, in the Mouse Mutant Resource at The Jackson Laboratory, we discovered a small mouse phenotype that arose as a spontaneous autosomal recessive mutation on a congenic C3.SW- $H 2^{b} / \mathrm{SnJ}$ inbred background. Molecular genetic studies revealed that this mutation, designated small (allele symbol $s m l$ ), was due to a frameshift mutation in the Irs 1 gene. This report details the molecular and phenotypic characterization of this mutant and the cellular changes that occur in response to altered IRS-1 signaling. Findings from this study add to insights gained from previous work using genetic engineering, and raise important questions about the inter-relationship between the IGF1 regulatory system and bone acquisition.

\section{Materials and Methods}

\section{Mouse husbandry}

The $\operatorname{Irs} 1^{\text {sml }}$ allele is a spontaneous mutation that occurred in an inbred C3.SW-H $2^{b} / \mathrm{SnJ}$ mouse strain. All mice used in this study were produced and maintained in our research colony at The Jackson Laboratory (Bar Harbor, ME, USA). Mice were housed in groups of 4 or 5 of the same sex within polycarbonate boxes of $324 \mathrm{~cm}^{2}$ in area on sterilized shavings of Northern White Pine. Colony environmental conditions included $14 \mathrm{~h}$ light: $10 \mathrm{~h}$ darkness cycles, with free access to acidified water ( $\mathrm{pH} 2.5$ with $\mathrm{HCl}$ to retard bacterial growth) and irradiated NIH-31 diet containing $6 \%$ fat, $19 \%$ protein, Ca:P $1 \cdot 15: 0 \cdot 85$, plus vitamin and mineral fortified (Purina Mills International, Gray Summit, MO, USA). All studies were conducted using groups of mutant, heterozygous, and wild-type male and female mice. All procedures involving mice were reviewed and approved by the Institutional Animal Care and Use Committee of The Jackson Laboratory.

\section{Genetic mapping}

To map the $\mathrm{sml}$ mutation, $204 \mathrm{~F}_{2}$ mice were produced from an intercross between (C3.SW-H2 $\left.2^{b} / \mathrm{SnJ}-s m l \times \mathrm{CAST} / \mathrm{Ei}\right) \mathrm{F}_{1}$ hybrid mice. Genomic DNA from $\mathrm{F}_{2}$ mice was prepared and genotyped using Mit marker primer pairs as described previously (Gagnon et al. 2006). The sml mutation was mapped utilizing recombination frequencies and the Map Manager Program (Manly et al. 2001).

\section{Sequencing of the Irs1 gene}

PCR primers used to amplify exons 1 and 2 of the mouse Irs 1 gene for sequence comparisons between mutant and control are given in Table 1. PCR conditions were described previously (Gagnon et al. 2006). PCR-amplified products were purified using the Qiaquick PCR Purification Kit (Qiagen Inc). DNA was sequenced using an Applied Biosystems 373A DNA Sequencer (Applied Biosystems, Foster City, CA, USA). The same primers that were used for PCR amplification were also used for sequencing.

\section{Genotyping of the $\operatorname{Irs} 1^{\mathrm{sml}}$ colony}

To genotype this mouse colony, we recognized that the deletion of the one adenine nucleotide in exon 1 created a restriction enzyme recognition site, which Taq1 recognizes (T-CGA). We designed primers (Irs1 $\mathrm{F}$ 5'-CAA GGA GGT 
Table 1 Irs 1 gene amplification and sequencing primers

Primer sequence $5^{\prime}$ to $3^{\prime}$

E1-1F GACTGGGGGAGACATAGTCC

E1-1R TCCAGAGGAGCAAAACACGTGA

E1-2F CCTTTGCCCGATTATGCAG

E1-2R TGCTCGAGTCCGATGTAGG

E1-3F AGTACCAGTGGCCATGGCT

E1-3R CCTTTGCCCGATTATGCAG

E1-4F TCATTAACCCCATCAGACGC

E1-4R GTGCTAGGGCTCACAGGACT

E1-5F CAACAGCAGCAGCAGTCTTC

E1-5R AGGAGACATGGGCATATAGCC

E1-6F GAGCAGGGGCTGCAGTAG

E1-6R CTGTTGGTCTGTGCAGCTGT

E1-7F GGAAGGGTCAGGGTACACAG

E1-7R CTTGAGTGTCTGCGCGAAT

E1-2F AAAATGTAGCTTTCATTACAGCACA

E2-1R AATACGGAGAGCTCACCCCT

E2-2F TTCATACATTGCCTCCGAGA

E2-2R CTCTCCACCCAACATGAACA

E2-3F CCTACCTTGTGTGTTCTGGGA

E2-3R CAAATTCTAAGCCGACACTTG
Product size

804

794

856

930

818

826

642

583

725

433

CTG GCA GGT TA-3' and Irs 1 R $5^{\prime}$-CCC ACC TCG ATG AAG AAG AA- $3^{\prime}$ ) to amplify the region of interest and then digested them with Taq1 restriction enzyme as per the manufacturer's instructions. The digested products yielded a control band of $190 \mathrm{bp}$, with a mutant band of $171 \mathrm{bp}$.

\section{Quantitative real-time PCR}

RNA was extracted from the femurs of four 8-week-old $\operatorname{Irs} 1^{s m l / s m l}$ and $\operatorname{Irs} 1^{+/+}$control mice as described previously (DeMambro et al. 2008). Briefly, femurs were isolated and snap frozen in liquid nitrogen, and RNA was then isolated using the Total RNA isolation system (Promega) as per the manufacturer's instructions. DNA was then removed from the RNA samples using the DNA-free DNase Treatment \& Removal Reagents (Ambion, Inc., Austin, TX, USA). RNA quality and quantity were assessed using an Agilent bioanalyzer (Caliper Technologies Corp., Hopkinton, MA, USA). Four hundred nanograms of RNA were then converted to cDNA in a reverse transcription reaction using the MessageSensor RT Kit (Ambion, Inc.) and random decamers as primers. The cDNA was then diluted 1:5 with water. Quantification of mRNA expression was carried out using an iQ SYBR Green Supermix in a iQ5 thermal cycler and detection system (Bio-Rad). GAPDH was used as an internal standard control gene for all quantifications. Primer sequences used in this study are as follows: RANKL (forward: 5'-TAC TTT CGA GCG CAG ATG GAT-3' and reverse: 5'-CTG CGT TTT CAT GGA GTC TCA-3'), osteoprotegerin (forward: $5^{\prime}$-TCC GGC GTG GTG CAA G-3' and reverse: 5'-AGA ACC CAT CTG GAC ATT TTT TG-3'), and GAPDH (forward: $5^{\prime}$-TGA ACG GGA AGC TCA CTG G-3' and reverse: $5^{\prime}$-TCC ACC ACC CTG TTG CTG TA-3').

\section{Western blotting}

Mouse livers were collected, frozen in liquid nitrogen, and stored at $-80{ }^{\circ} \mathrm{C}$ until processing. Total cellular protein lysates were prepared in a buffer consisting of $50 \mathrm{mM}$ Tris base (pH 8.2), $150 \mathrm{mM} \mathrm{NaCl}, 1 \%$ Igepal, and complete protease inhibitor cocktail tablets (Roche) for $30 \mathrm{~min}$ at $4{ }^{\circ} \mathrm{C}$, followed by centrifugation at $10000 \mathrm{~g}$ for $20 \mathrm{~min}$ at $4{ }^{\circ} \mathrm{C}$. For immunoprecipitation, cell lysates were incubated with a rabbit anti-C-terminus IRS-1 antibody (Upstate \#06-248, Millapore, Billerica, MA, USA) for $1 \mathrm{~h}$ at $4{ }^{\circ} \mathrm{C}$. The immunocomplexes were then collected using an Immunoprecipitation Kit Protein A (\#1719394 Roche) as per the manufacturer's instructions. Proteins were resolved on 10\% SDS-polyacrylamide gels and transferred to polyvinylidene fluoride (PVDF) membranes (Millipore). Membranes were blocked with 5\% non-fat dry milk (Bio-Rad), and were then incubated with the same anti-C-terminus IRS-1 antibody followed by a HRP-conjugated donkey anti-rabbit antibody (Santa Cruz \#sc-2317). Signal was detected using an enhanced chemiluminescence kit (Amersham).

The calvarial cells post treatment were washed twice with ice-cold PBS and resuspended in a lysis radioimmunoprecipitation assay buffer supplemented with protease and phosphatase inhibitors (Sigma-Aldrich). Cell lysates were homogenized by rotating at $4{ }^{\circ} \mathrm{C}$ for $30 \mathrm{~min}$ and were then centrifuged at $10000 \mathrm{~g}$ for $20 \mathrm{~min}$ at $4{ }^{\circ} \mathrm{C}$. Protein concentrations were measured in the supernatant using Bradford's reagent (Bio-Rad). Proteins were resolved on $10 \%$ SDS-polyacrylamide gels and transferred to PVDF membranes. Membranes were incubated with antibodies for phosphorylated AKT (pAKT; Cell Signaling \#9271, Danvers, MA, USA) or total AKT (tAKT; Cell Signaling \#9272) followed by HRP-conjugated goat anti-rabbit antibody (Cell Signaling \#7074). In a separate set of experiments, calvarial cells post treatment were immunoprecipitated with an IRS-2 (Millipore \# 06-506) antibody subjected to SDS-PAGE as described above and were then incubated with a phosphotyrosine-specific antibody (Millipore \#05-321).

\section{Assessment of hearing by auditory brainstem response}

Groups of female and male $\operatorname{Irs} 1^{\mathrm{sml} / \mathrm{sml}}$ and littermate $\operatorname{Irs} 1^{+/ \mathrm{sml}}$ mice $(n=7-10)$ between 8 and 12 weeks of age were anesthetized with Avertin (tribromoethanol stabilized in tertiary amyl hydrate) given at a dose of $5 \mathrm{mg}$ tribromoethanol/10 g body weight. Body temperature was maintained at $37-38{ }^{\circ} \mathrm{C}$ by placing the mice on an isothermal pad in a sound-attenuating chamber. Sub-dermal needles were used as electrodes, which were inserted at the vertex and ventrolaterally to each ear. Stimulus presentation, auditory brainstem response (ABR) acquisition, equipment control, and data management were coordinated using the computerized Intelligent Hearing Systems (IHS, Miami, FL, USA). A pair of high frequency transducers were coupled with the IHS to 
generate specific acoustic stimuli. Clicks and 8, 16, and $32 \mathrm{kHz}$ tone bursts were respectively channeled through plastic tubes into the animals' ear canals. The amplified brainstem responses were averaged by a computer and displayed on the computer screen. Auditory thresholds were obtained for each stimulus by reducing the sound pressure level at $10 \mathrm{~dB}$ steps and finally at $5 \mathrm{~dB}$ steps up and down to identify the lowest level at which an ABR pattern can be recognized (Gagnon et al. 2006).

\section{Sample collection for phenotypic studies}

For body composition and bone phenotyping (dual energy X-ray absorptiometry (DEXA), pQCT, and micro-computed tomography (MicroCT)), groups of female and male $\operatorname{Irs} 1^{\mathrm{sml} / \mathrm{sml}}$, littermate $\operatorname{Irs} 1^{+/ \mathrm{sml}}$, and Irs $1^{+/+}$control mice $(n=10)$ were necropsied and measured at $4,8,12$, and 16 weeks of age. All time points showed the same pattern and statistical significance, thus for the simplicity of presentation, only the 16-week data are reported here. For each mouse, whole body weight was recorded, whole body DEXA scans were gathered, and tissue samples were collected. Skeletal preparations were prepared as described previously (Beamer et al. 2007, DeMambro et al. 2008). Serum was harvested from the whole blood collected at necropsy and was stored at $-20{ }^{\circ} \mathrm{C}$ until assayed for hormones.

\section{PIXImus for areal BMD}

Groups of Irs $1^{s m l / s m l}$, littermate Irs $1^{+/ s m l}$, and Irs $1^{+/+}$control female and male mice were measured at 4, 8, 12, and 16 weeks $(n=10)$ for lean muscle mass, fat, and bone mineral using the PIXImus dual-energy X-ray densitometer (GE-Lunar, Madison, WI, USA). The PIXImus was calibrated daily with a mouse phantom provided by the manufacturer. Mice were placed ventral side down with each limb and tail positioned away from the body. Full body scans were obtained, and X-ray absorptiometry data were gathered and processed with the manufacturer's supplied software (Lunar PIXImus 2, version 2.1). The head was specifically excluded from all analyses due to concentrated mineral in skull and teeth.

\section{$p Q C T$ for volumetric BMD bone densitometry}

Volumetric BMD (vBMD) was measured on the left femur from groups $(n=10)$ of female and male $\operatorname{Irs} 1^{\mathrm{sml} / \mathrm{sml}}$, littermate $\operatorname{Irs} 1^{+/ s m l}$, and $\operatorname{Irs} 1^{+/+}$control mice at $4,8,12$, and 16 weeks of age. Isolated femur lengths were measured with digital calipers (Stoelting, Wood Dale, IL, USA), and femurs were then measured for density using the SA Plus densitometer (Orthometrics, White Plains, NY, USA). Calibration of the SA Plus instrument was performed daily, and femurs were analyzed as described previously (DeMambro et al. 2008).

\section{MicroCT40}

Femurs from female and male Irs $1^{\mathrm{sml} / \mathrm{sml}}$, littermate $I r s 1^{+/ s m l}$, and $I r 1^{+/+}$control mice were scanned using MicroCT40 (Scanco Medical AG, Bassersdorf, Switzerland) to evaluate trabecular bone volume fraction and microarchitecture in the metaphyseal region of the distal femur. In addition, cortical thickness data were obtained at the mid-shaft. The MicroCT40 unit was calibrated weekly, and femurs were scanned under conditions described previously (DeMambro et al. 2008).

\section{Bone histomorphometry}

To determine whether the in vivo histomorphometry differences seen between the $\operatorname{Irs} 1^{\mathrm{sml} / \mathrm{sml}}$ and the Irs $1^{\text {tm 1Tka/tm 1Tka }}$ mice were the result of gender differences, we studied groups of Irs $1^{\text {sml } / s m l}$ and Irs $1^{+/+}$females and males $(n=6)$ at 13 weeks of age. Mice were injected with $20 \mathrm{mg} / \mathrm{kg}$ calcein i.p. and with $50 \mathrm{mg} / \mathrm{kg}$ demeclocycline 7 days later. Mice were sacrificed $48 \mathrm{~h}$ following the demeclocycline injection. Femurs were then analyzed as described previously (DeMambro et al. 2008). A separate experiment in which Irs $1^{\text {sml } / s m l}$ and Irs $1^{+/ s m l}$ females were evaluated was then used for comparison with the Irs $1^{+/+}$females for the presence of any heterozygous effects. The terminology and units used are those recommended by the Histomorphometry Nomenclature Committee of the American Society for Bone and Mineral Research (Parfitt et al. 1987).

\section{Osteoblast and osteoclast cultures}

Bone marrow cells were harvested from femurs and tibias of 8 -week-old mice. Osteoclast-like cells were generated by plating bone marrow stromal cells at $10 \times 10^{6} /$ well on six-well plates in $\boldsymbol{\alpha}$-MEM (Invitrogen) and $10 \%$ fetal bovine serum (FBS). Osteoclast-like cells were generated by plating bone marrow stromal cells at $1 \times 10^{6}$ cells/well in 48 -well plates in $\boldsymbol{\alpha}$-MEM supplemented with 10\% FCS and M-CSF (30 ng/ml, PeproTech Inc., Rocky Hill, NJ, USA) and RANKL (50 ng/ml PeproTech). Cultures were maintained, fixed, stained, and analyzed as described previously (DeMambro et al. 2008).

Mouse calvarial osteoblasts were harvested from 3- to 6-day-old pups using standard methods (http://skeletalbiology.uchc.edu/30_ResearchProgram/304_gap/index.htm). The cells were cultured in 10\% FBS $\alpha$-MEM to $90 \%$ confluence and were then serum starved in $0 \cdot 1 \%$ FBS for $24 \mathrm{~h}$ to reduce cellular activity to quiescent levels. Cells were treated with insulin $(100 \mathrm{nM})$ or IGF1 $(100 \mathrm{ng} / \mathrm{ml})$ for $15 \mathrm{~min}$ and were then harvested for western blot analysis. Data presented for cell culture experiments correspond to three independent experiments with at least three replicate cultures within each experiment. 
Table 2 Auditory brainstem response in $\operatorname{Irs} 1^{+/ s m l}$ and $\operatorname{lrs} 1^{\mathrm{sml} / \mathrm{sm} /}$ mice

\begin{tabular}{|c|c|c|c|c|}
\hline & +/sml Males & $s m l / s m l$ Males & $+/ s m /$ Females & $s m l / s m /$ Females \\
\hline & $n=7$ & $n=9$ & $n=10$ & $n=12$ \\
\hline Click & $34 \cdot 3 \pm 1 \cdot 7$ & $51 \cdot 1 \pm 5 \cdot 9^{*}$ & $33 \cdot 5 \pm 0 \cdot 8$ & $53 \cdot 8 \pm 5 \cdot 2^{*}$ \\
\hline $8 \mathrm{kHz}$ & $27 \cdot 9 \pm 4 \cdot 6$ & $50 \cdot 0 \pm 6 \cdot 5^{*}$ & $23 \cdot 5 \pm 1 \cdot 1$ & $55 \cdot 0 \pm 6 \cdot 2^{*}$ \\
\hline $16 \mathrm{kHz}$ & $15 \cdot 7 \pm 4 \cdot 6$ & $34 \cdot 4 \pm 7 \cdot 1^{*}$ & $16 \cdot 0 \pm 1 \cdot 0$ & $36 \cdot 7 \pm 5 \cdot 3^{*}$ \\
\hline $32 \mathrm{kHz}$ & $40 \cdot 0 \pm 2 \cdot 7$ & $61 \cdot 7 \pm 6 \cdot 1 *$ & $41 \cdot 0 \pm 1 \cdot 0$ & $66 \cdot 3 \pm 5 \cdot 4 *$ \\
\hline
\end{tabular}

$* P<0 \cdot 05+/ s m l$ versus $\mathrm{sml} / \mathrm{sml}$.

\section{Serum IGF1 and insulin}

Serum IGF1 levels were measured by RIA (ALPCO, Windham, NH, USA) as reported previously (Rosen et al. 2000, 2004, Delahunty et al. 2006). Serum insulin was measured by RIA (LINCO Research, St Charles, MO, USA) as per the manufacturer's instructions. The sensitivities of the assays were $0 \cdot 01 \mathrm{ng} / \mathrm{ml}$ for IGF1 and $0 \cdot 1 \mathrm{ng} / \mathrm{ml}$ for insulin. The intra-assay coefficient of variation for the assays was $4 \cdot 5-4 \cdot 6 \%$. All samples were analyzed within the same assay.

\section{Glucose and insulin tolerance tests}

Female and male $\operatorname{Irs} 1^{\text {sml/sml }}, \operatorname{Irs} 1^{+/ s m l}$, and Irs $1^{+/+}$mice were tested at 8 and 12 weeks of age for glucose and insulin tolerance. For the glucose tolerance test (GTT), mice were placed in a clean cage with water and fasted overnight (16 h). A $1 \mathrm{~g} / \mathrm{kg}$ dose of glucose was administered i.p., and blood glucose levels were measured at 0, 20, 40, 60, and $120 \mathrm{~min}$ post injection. For the insulin tolerance test (ITT), mice were fed ad libitum and injected i.p. with insulin at a dose of $1 \mathrm{U} / \mathrm{kg}$. Glucose levels were then measured at 0, 20, 40, 60, and $120 \mathrm{~min}$ post injection.

Glucose levels were measured using the OneTouch Ultra Glucometer (LifeScan, Inc., Milpitas, CA, USA) as per the manufacturer's instructions (Messier \& Kent 1995, Weitgasser et al. 1999). In a separate experiment, we verified the accuracy and precision of the most recently manufactured OneTouch Ultra portable glucometers against Beckman Synchron CX5 Delta Clinical System (Beckman Coulter, Brea, CA, USA) using blood samples from 8- to 12-week-old C57BL6/J mice $(n=16)$. This comparison confirmed that glucose levels reported using portable glucometers correlated highly $\left(r^{2}=0.92\right)$ against the glucose levels reported by the Beckman Synchron CX5 Delta Clinical System (data not shown).

\section{Statistical assessment}

Statistical tests were performed using JMP version 6.0 software (SAS, Cary, NC, USA) and StatView version 5.0.1 software (SAS). For the DEXA, pQCT, and MicroCT40 data, differences among $\operatorname{Irs} 1^{\text {sml/sml }}, \operatorname{Irs} 1^{+/ s m l}$, and $\operatorname{Irs} 1^{+/+}$ mice were taken into account by including body weight and femur length as covariates in an ANCOVA model.
Neither covariate was found to contribute to any of the mutant phenotypes. Data are expressed as mean \pm s.E.M. in all figures. Differences between means were tested by ANOVA, with significance being declared when a $P \leq 0.05$ was observed.

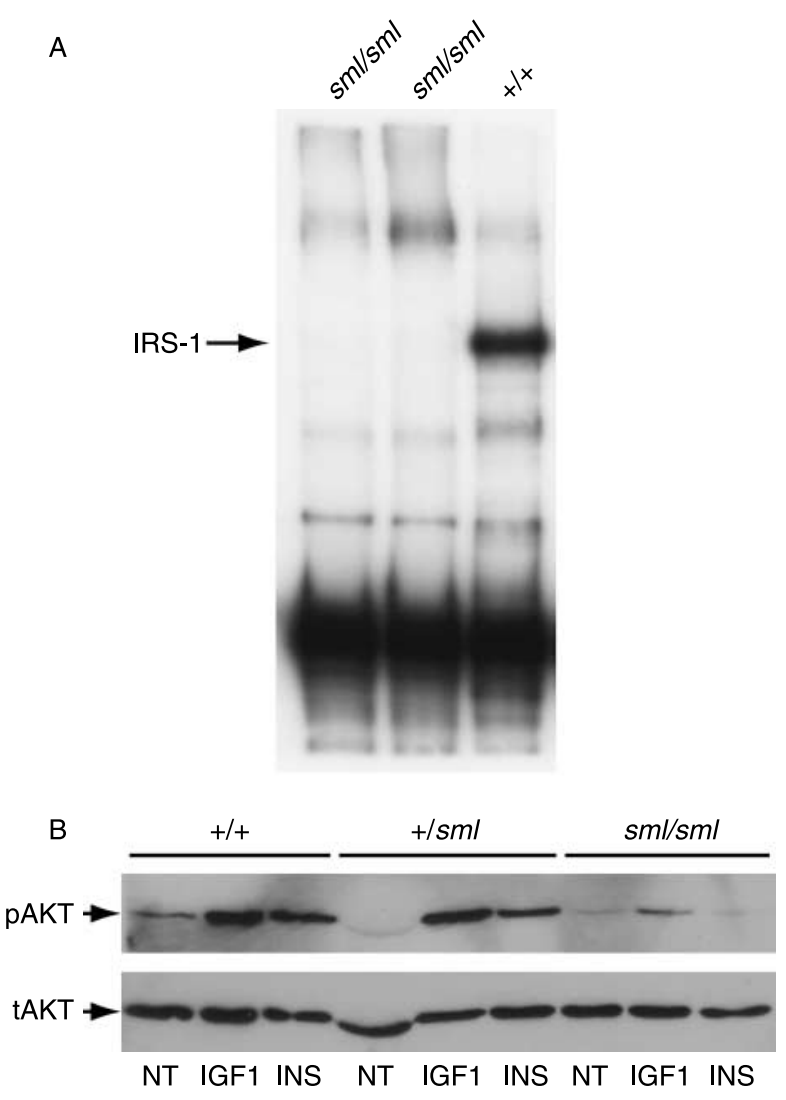

Figure 1 Western blots of IRS-1 (A) and AKT (B). (A) Liver lysates from $I r s 1^{\mathrm{sml} / \mathrm{sml}}$ mice (lanes $1-2$ ) and an $I r s 1^{+/+}$control (lane 3) were immunoprecipitated with an IRS-1 C-terminus-specific antibody as described in the Materials and Methods. Following SDS-PAGE, the amount of IRS-1 was determined by immunoblotting. The arrow denotes the position of the IRS- 1 band which is lacking in $I r s 1^{\mathrm{sml} / \mathrm{sm} /}$ lysates. (B) Mouse calvarial osteoblast cultures from $I r s 1^{\mathrm{sml} / \mathrm{sml}}, \operatorname{Irs} 1^{+/ \mathrm{sml} l}$, and Irs $1^{+/+}$mice were treated with IGF1 (IGF1) and insulin (INS) or were given no treatment (NT), harvested, and lysed as described in the Materials and Methods. Following SDS-PAGE, membranes were immunoblotted for phosphorylated AKT (pAKT) and total AKT (tAKT). 


\section{Results}

History of the $\operatorname{Irs} 1^{\mathrm{sml}}$ mutation

The original $\operatorname{Irs} 1^{\text {sml }}$ mutant was backcrossed to the C3.SW$H 2^{b} / \mathrm{SnJ}$ parental strain resulting in no mutants being observed in the F1 progeny. However, the expected Mendelian ratio of 3:1 unaffected:affected for a recessive mutation was observed in the F2 progeny. Gross histological examination found no lesions in any major organs other than decreased size (data not shown). No eye defects were detected. Hearing was assessed by ABR, and both male and female mutant mice exhibited significantly higher thresholds at 8,16 , and $32 \mathrm{kHz}$ than the control littermates, indicative of hearing impairment in these mice (Table 2). Histological examination of the inner ear found no obvious defects.

Genetic mapping and mutation analysis of the $\operatorname{Irs} 1^{\mathrm{sml}}$ mutation

The F2 progeny from an intercross with CAST/Ei were used to map the $s m l$ mutation to chromosome 1 between D1Mit216 $(79 \cdot 8 \mathrm{Mb})$ and D1Mit440 $(90 \cdot 7 \mathrm{Mb})$. Analysis of 204 F2 mice (408 meioses) positioned sml between D1Mit216 $(79 \cdot 8 \mathrm{Mb}, 1 \cdot 23 \%$ recombination) and D1Mit440 $(90 \cdot 7 \mathrm{Mb}$, $2 \cdot 45 \%$ recombination). Irs 1 is located at $82 \cdot 2 \mathrm{Mb}$, and was considered a prime candidate for this mutation because of the smaller size of a knockout model reported previously (see Introduction).

Genomic DNA from Irs $1^{\text {sml/sml }}$ mice and Irs $1^{+/+}$controls was analyzed for the Irs 1 gene by PCR amplification using overlapping primer pairs (Table 1) and sequence analysis. We discovered a deletion of one adenine nucleotide in exon 1 at position $1559 \mathrm{bp}$. This deletion results in a frameshift mutation changing a glutamine to an arginine residue, which produces a premature stop codon, predicted to result in a truncated protein of 211 amino acids instead of the full-length 1233-amino acid protein.

To confirm this mutation, we recognized that the deletion of the one adenine nucleotide created a restriction enzyme recognition site, which Taq1 recognizes (T-CGA). Thus, the region of interest was amplified, and Taq1 digestion yielded the control product of $190 \mathrm{bp}$, with a mutant product of $171 \mathrm{bp}$, confirming the deletion. Quantification of Irs 1 mRNA levels by real-time RT-PCR revealed no differences in expression between the $\operatorname{Irs} 1^{+/+}$and the $\operatorname{Irs} 1^{\mathrm{sml} / \mathrm{sml}}$ mice (data not shown). Western blot analysis of proteins from the livers of the $\operatorname{Irs} 1^{s m l / s m l}$ and $\operatorname{Irs} 1^{+/+}$control mice using a C-terminus-specific IRS-1 antibody revealed that the $\operatorname{Irs} 1^{s m l / s m l}$ mice had no detectable IRS-1 protein (Fig. 1A).

\section{Body composition by DEXA}

Homozygous male and female Irs $1^{\text {sml } / s m l}$ mice are phenotypically recognizable at $\sim 2$ weeks of age by their smaller size and thin short tails, a condition that persists throughout their lives despite normal GH levels. After weaning, mutants are $\sim 60 \%$ the size of their Irs $1^{+/ s m l}$ control littermates, including a $20 \%$ reduction in tail length (Table 3 ). Whole body DEXA analysis at 16 weeks of age revealed that $\operatorname{Irs} 1^{\mathrm{sml} / \mathrm{sml}}$ male and female mice had reduced percent fat and aBMD compared with the Irs $1^{+/+}$controls. Irs $1^{+/ s m l}$ heterozygous mice had lower body weight, aBMD, and percent fat than the $\operatorname{Irs} 1^{+/+}$ mice, but these parameters were greater than those of the Irs $1^{\text {sml/sml }}$ mutants (Table 3 ).

\section{Skeletal microstructure by $p Q C T$ and MicroCT}

Analysis of femurs isolated from 16-week-old $\operatorname{Irs} 1^{+/+}$, $\operatorname{Irs} 1^{+/ s m l}$, and $\operatorname{Irs} 1^{\text {sml/sml }}$ mice revealed that $\operatorname{Irs} 1^{\text {sml/sml }}$ male and female mice had significant reductions in femur length, with an overall reduction in vBMD as measured by $\mathrm{pQCT}$ when compared with the $\operatorname{Irs} 1^{+/+}$control mice. Irs $1^{\text {sml/sml }}$ femurs also exhibited a reduction in cortical thickness as well as in periosteal circumference (Table 3). MicroCT analysis confirmed the reduction in cortical thickness with a smaller cortical bone area/total area (percent BA/TA). The distal femoral trabecular bone exhibited a significant reduction in

Table 3 Body composition and bone phenotype of $I r s 1^{+/+}, I r s 1^{+/ s m l}$, and $I r s 1^{\mathrm{sml} / \mathrm{sm} /}$ mice by DEXA, pQCT, and micro-computed tomography at 16 weeks of age

\begin{tabular}{lc}
\cline { 2 - 2 } Body weight & $37 \cdot 9 \pm 1 \cdot 0$ \\
F. length $(\mathrm{mm})$ & $15 \cdot 58 \pm 0 \cdot 07$ \\
Percent fat & $32 \cdot 8 \pm 0 \cdot 8$ \\
aBMD $\left(\mathrm{g} / \mathrm{cm}^{2}\right)$ & $0 \cdot 057 \pm 0 \cdot 001$ \\
vBMD $\left(\mathrm{mm} / \mathrm{cm}^{3}\right)$ & $0 \cdot 83 \pm 0 \cdot 01$ \\
Peri. circ. $(\mathrm{mm})$ & $4 \cdot 79 \pm 0 \cdot 03$ \\
BA/TA $(\%)$ & $79 \cdot 0 \pm 0 \cdot 7$ \\
CortTh $(\mathrm{mm})$ & $37 \cdot 14 \pm 0 \cdot 66$ \\
BV/TV $(\%)$ & $22 \cdot 0 \pm 1 \cdot 4$ \\
TbN $(/ \mathrm{mm})$ & $4 \cdot 4 \pm 0 \cdot 1$ \\
TbTh $(\mathrm{mm})$ & $73 \cdot 9 \pm 2 \cdot 7$
\end{tabular}

\begin{tabular}{c}
$+/$ sm I Males \\
\hline $32 \cdot 3 \pm 0 \cdot 9^{*}$ \\
$15 \cdot 08 \pm 0 \cdot 11^{*}$ \\
$28 \cdot 5 \pm 1 \cdot 2^{*}$ \\
$0 \cdot 05 \pm 0 \cdot 001^{*}$ \\
$0 \cdot 73 \pm 0 \cdot 01^{*}$ \\
$4 \cdot 62 \pm 0 \cdot 04^{*}$ \\
$75 \cdot 2 \pm 1 \cdot 1^{*}$ \\
$33 \cdot 26 \pm 0 \cdot 75^{*}$ \\
$21 \cdot 0 \pm 0 \cdot 8$ \\
$4 \cdot 8 \pm 0 \cdot 1$ \\
$66 \cdot 3 \pm 1 \cdot 3^{*}$
\end{tabular}

\begin{tabular}{c} 
sml/sml Males \\
\hline $16 \cdot 5 \pm 0 \cdot 7^{+, \neq}$ \\
$12 \cdot 55 \pm 0 \cdot 04^{t, \neq}$ \\
$20 \cdot 6 \pm 1 \cdot 9^{+, \neq}$ \\
$0 \cdot 039 \pm 0 \cdot 001^{+, \neq}$ \\
$0 \cdot 65 \pm 0 \cdot 01^{+, \neq}$ \\
$3 \cdot 73 \pm 0 \cdot 02^{+, \neq}$ \\
$71 \cdot 3 \pm 0 \cdot 8^{+, \neq}$ \\
$25 \cdot 14 \pm 0 \cdot 44^{+, \neq}$ \\
$15 \cdot 4 \pm 0 \cdot 9^{+, \neq}$ \\
$5 \cdot 3 \pm 0 \cdot 2^{+, \neq}$ \\
$49 \cdot 3 \pm 0 \cdot 7^{+, \neq}$
\end{tabular}

\begin{tabular}{c}
$+/+$ Females \\
\hline $35 \cdot 6 \pm 1 \cdot 1$ \\
$15 \cdot 47 \pm 0 \cdot 09$ \\
$39 \cdot 9 \pm 1 \cdot 4$ \\
$0 \cdot 058 \pm 0 \cdot 001$ \\
$0 \cdot 86 \pm 0 \cdot 01$ \\
$4 \cdot 70 \pm 0 \cdot 02$ \\
$81 \cdot 3 \pm 0 \cdot 4$ \\
$38 \cdot 32 \pm 0 \cdot 43$ \\
$28 \cdot 3 \pm 1 \cdot 2$ \\
$4 \cdot 2 \pm 0 \cdot 1$ \\
$89 \cdot 6 \pm 1 \cdot 1$
\end{tabular}

\begin{tabular}{c}
$+/$ sm I Females \\
\hline $31 \cdot 9 \pm 1 \cdot 2^{*}$ \\
$14 \cdot 99 \pm 0 \cdot 11^{*}$ \\
$35 \cdot 3 \pm 1 \cdot 3^{*}$ \\
$0 \cdot 049 \pm 0 \cdot 001^{*}$ \\
$0 \cdot 76 \pm 0 \cdot 01^{*}$ \\
$4 \cdot 28 \pm 0 \cdot 03^{*}$ \\
$79 \cdot 2 \pm 0 \cdot 6^{*}$ \\
$34 \cdot 14 \pm 0 \cdot 47^{*}$ \\
$26 \cdot 2 \pm 0 \cdot 6$ \\
$4 \cdot 1 \pm 0 \cdot 1$ \\
$85 \cdot 5 \pm 1 \cdot 7^{*}$
\end{tabular}

$s m l / s m l$ Females

$15 \cdot 4 \pm 0 \cdot 4^{+, \neq}$ $12 \cdot 83 \pm 0 \cdot 06^{+, \neq}$ $16 \cdot 8 \pm 1 \cdot 4^{+, \neq}$ $0 \cdot 038 \pm 0 \cdot 001^{+, \neq}$ $0 \cdot 66 \pm 0 \cdot 01^{+, \neq}$ $3 \cdot 61 \pm 0 \cdot 03^{+, \neq}$ $73 \cdot 9 \pm 0 \cdot 4^{+, \neq}$ $25 \cdot 3 \pm 0 \cdot 20^{+, \neq}$ $7 \cdot 5 \pm 0 \cdot 7^{+, \neq}$ $2 \cdot 8 \pm 0 \cdot 2^{\dagger, \neq}$ $51 \cdot 8 \pm 0 \cdot 8^{\dagger, \neq}$

$n=10,{ }^{*} P<0.05++$ versus $+/ \mathrm{sml},{ }^{+} P<0.0001+/+$ versus $\mathrm{sml} / \mathrm{sml},{ }^{\ddagger} P<0.0001+/ \mathrm{sm} /$ versus $\mathrm{sml} / \mathrm{sml}$. F. length, femur length; Peri. circ., periosteal circumference; BA/TA, bone area/total area; CortTh, cortical thickness; BV/TV, bone volume/total volume; TbN, trabecular number; TbTh, trabecular thickness. 
Table 4 Histomorphometry of $I r s 1^{+/+}$and $I r s 1^{\mathrm{sm} / / \mathrm{sm} /}$ distal femurs at 13 weeks of age

\begin{tabular}{|c|c|c|c|c|}
\hline & $+/+$ Males & $s m l / s m l$ Males & $+/+$ Females & $s m l / s m /$ Females \\
\hline Nob/BPm (/mm) & $28 \cdot 00 \pm 1 \cdot 23$ & $29 \cdot 82 \pm 2 \cdot 12$ & $27 \cdot 28 \pm 1 \cdot 52$ & $31 \cdot 83 \pm 1 \cdot 05^{*}$ \\
\hline $\mathrm{ES} / \mathrm{BS}(\%)$ & $12 \cdot 5 \pm 1 \cdot 29$ & $13 \cdot 58 \pm 1 \cdot 69$ & $12 \cdot 87 \pm 1 \cdot 22$ & $17 \cdot 06 \pm 0 \cdot 67^{*}$ \\
\hline MS/BS (\%) & $6 \cdot 89 \pm 0 \cdot 51$ & $2 \cdot 41 \pm 0 \cdot 38^{*}$ & $7 \cdot 14 \pm 0 \cdot 84$ & $4 \cdot 10 \pm 0 \cdot 32 *$ \\
\hline MAR ( $\mu \mathrm{m} /$ day) & $0 \cdot 441 \pm 0 \cdot 026$ & $0 \cdot 290 \pm 0 \cdot 024 *$ & $0 \cdot 640 \pm 0 \cdot 027$ & $0 \cdot 439 \pm 0 \cdot 047^{*}$ \\
\hline BFR/BS $\left(\mu \mathrm{m}^{3} / \mu \mathrm{m}^{2}\right.$ per day) & $0.031 \pm 0.003$ & $0 \cdot 007 \pm 0 \cdot 001^{*}$ & $0 \cdot 046 \pm 0 \cdot 006$ & $0 \cdot 017 \pm 0 \cdot 003^{*}$ \\
\hline
\end{tabular}

$n=6, * P \leq 0 \cdot 05$. Percent BV/TV, bone volume/total volume; Tb. Th, trabecular thickness; Nob/BPm, number of osteoblasts/bone perimeter; Noc/BPm, number of osteoclasts/bone perimeter; ES/BS, eroded surface/bone surface; MS/BS, mineral surface/bone surface; MAR, mineral apposition rate; BFR/BS, bone formation rate/bone surface.

bone volume/total volume (percent BV/TV) in both the female and male $I r s 1^{s m l / s m l}$ mice compared with the controls (Table 3). For the female mutants, this $73 \%$ reduction in $\mathrm{BV} / \mathrm{TV}$ was accompanied by a $33 \%$ decrease in trabecular number and a $42 \%$ reduction in trabecular thickness. However, the male mutants' distal femoral percent BV/TV was only reduced by $29 \%$ when compared with the controls. This gender difference was attributed to a $20 \%$ increase in trabecular number in the $\operatorname{Irs} 1^{\text {sml/sml }}$ male femurs. Although, increased in number, these trabeculae were 34\% thinner than those of the controls (Table 3).

Comparison of the $\operatorname{Irs} 1^{+/ s m l}$ female and male bones with those of the $I r s 1^{+/+}$and $\operatorname{Irs} 1^{s m l / s m l}$ mice revealed a significant intermediate phenotype for femur length, vBMD, and periosteal circumference (Table 3). Likewise, a significant intermediate phenotype was found at the mid-shaft for cortical thickness and percent BA/TA as measured by MicroCT. Interestingly, the heterozygous genotype did not affect percent $\mathrm{BV} / \mathrm{TV}$ or trabecular number in the distal femur compartment, although a slight but significant reduction in trabecular thickness was observed when compared with the $I r s 1^{+/+}$controls (Table 3 ).

\section{Histomorphometry}

Histomorphometry from the distal femur of male and female $\operatorname{Irs} 1^{+/+}$and $\operatorname{Irs} 1^{\mathrm{sml} / \mathrm{sml}}$ mice at 13 weeks of age showed a marked and significant decrease in the percent BV/TV analogous to what was observed by MicroCT. For both genders, the $\operatorname{Irs} 1^{s m l / s m l}$ mice had markedly reduced mineralizing surface/bone surface (percent MS/BS), mineral apposition rate (MAR), and bone formation rate (BFR). Furthermore, the numbers of osteoblasts and osteoclasts per bone perimeter (Nob/BPm and Noc/BPm) were increased in both genders of $\operatorname{Irs} 1^{s m l / s m l}$ mice compared with the $\operatorname{Irs} 1^{+/+}$ controls. However, this increase was only significant for Irs $1^{\text {sml/sml }}$ females (Table 4). Remarkably, there was no evidence of marrow adiposity in the histological sections of the $\operatorname{Irs} 1^{\mathrm{sml} / \mathrm{sml}}$ femurs compared with the $\operatorname{Irs} 1^{+/+}$femurs (Supplementary Figure 1, see section on supplementary data given at the end of this article). Inspection of the growth plate in the proximal femur revealed a marked reduction in thickness in the $\operatorname{Irs} 1^{s m l / s m l}$ mice compared with the $\operatorname{Irs} 1^{+/+}$ mice, which was consistent with their reduced bone length (Fig. 2). The Irs $1^{+/ s m l}$ growth plate was also mildly reduced compared with the $\operatorname{Irs} 1^{+/+}$mice.

Bone volume fraction by histomorphometry in the Irs $1^{+/ s m l}$ female mice at 13 weeks of age was not different from percent $\mathrm{BV} / \mathrm{TV}$ in the $I r s 1^{+/+}$mice, akin to the findings by MicroCT. However, osteoclast numbers per bone perimeter were significantly increased $(P<0 \cdot 05)$ in the Irs $1^{+/ s m l}$ heterozygote mice compared with the $I r s 1^{+/+}$ females, and there was a significant $(P<0 \cdot 05)$ reduction in MAR, although no statistical differences were noted in the overall BFRs nor eroded surfaces/bone surface (see Supplementary Table S1, see section on supplementary data given at the end of this article).

\section{Cell culture}

Alkaline phosphatase (ALP) staining of bone marrow stromal cell cultures of both male and female Irs $1^{\mathrm{sml} / \mathrm{sml}}$ mice on day 7 in culture revealed reductions in the number of CFU-ALP + pre-OBs compared with the Irs $1^{+/+}$cultures. Similarly, on days 18 and 24, the amount of ALP staining and mineral visually detected by von Kossa staining were less in the $\operatorname{Irs} 1^{\text {sml/sml }}$ mice than in the Irs $1^{+/ s m l}$ heterozygotes, and both were less than those detected in the $I r s 1^{+/+}$control cultures (Fig. 3). When non-adherent marrow cells were cultured in $\mathrm{m}-\mathrm{CSF}$ and RANKL, no differences in tartrate-resistant acid phosphatase-positive multinucleated cells were seen among mutant, heterozygote, or control mice (Fig. 3).

To determine if the increased osteoclast number in the $\operatorname{Irs} 1^{\mathrm{sml} / \mathrm{sml}}$ mice as noted by histomorphometry was related to
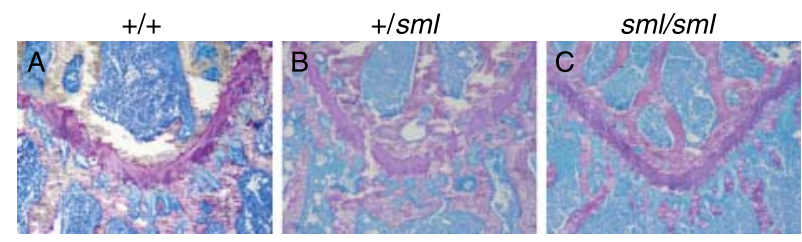

Figure 2 Toluidine blue staining of the proximal femur growth plate at $10 \times$ magnification of 13 -week-old $\operatorname{Irs} 1^{+/+}, \operatorname{Irs} 1^{+/ s m l}$, and $\operatorname{lrs} 1^{\mathrm{sml} / \mathrm{sml}}$ mice. 

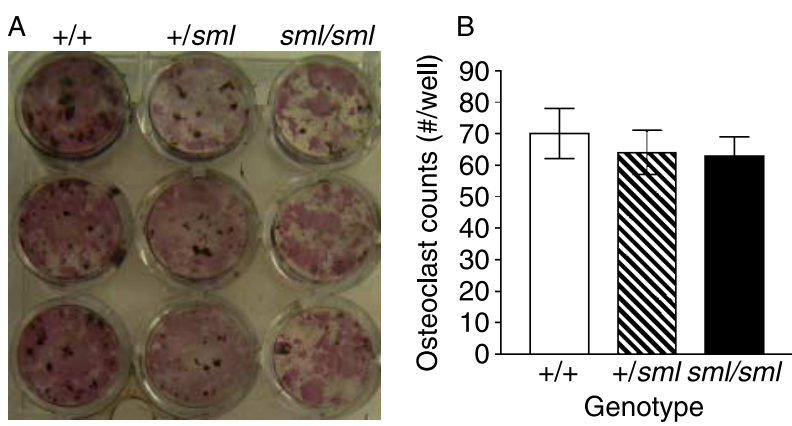

Figure 3 Bone marrow stromal cultures (BMSCs) of $\operatorname{lrs} 1^{\mathrm{sm} / / \mathrm{sm} /}$, Irs $1^{+/ s m l}$, and Irs $1^{+/+}$control females. (A) On day 18 , adherent $\mathrm{OB}$ progenitor cells were identified by alkaline phosphatase staining (CFU-ALP) and mineralization was identified by von Kossa staining. (B) Numbers of osteoclast cells in the bone marrow stromal cultures of $I r s 1^{\mathrm{sml} / \mathrm{sml} l}, \operatorname{Irs} 1^{+/ \mathrm{sml}}$, and $I r s 1^{+/+}$mice. On day 7 , the cells were fixed and stained for TRAP5b. TRAP5b-positive multinucleated ( $>3$ nuclei) osteoclasts were then counted using light microscopy. In all the experiments, male BMSCs exhibited a pattern that was similar to that exhibited by the females. Full colour version of this figure available via http://dx.doi.org/10.1677/JOE-09-0328.

the secretion of osteoclastogenic cytokines, we measured RANKL and OPG (listed as TNFRSF11B in the MGI Database) expression in calvarial osteoblasts and in 8-week-old femoral samples from the $\operatorname{Irs} 1^{\mathrm{sml} / \mathrm{sml}}$ and $\operatorname{Irs} 1^{+/+}$ controls. There were no statistical differences in RANKL expression by real-time PCR between mutants and controls from either site. Similarly for OPG, no strain differences were noted in calvarial osteoblast expression of Opg (Tnfrs 11b) mRNA, although in the femoral samples from the $\operatorname{Irs} 1^{\mathrm{sml} / \mathrm{sml}}$ mice, there was a modest but non-significant $(\sim 10 \%)$ reduction in OPG expression by real-time PCR compared with the controls.

Western blot analysis of the protein isolated from calvarial osteoblast cultures revealed that at baseline, both the $\operatorname{Irs} 1^{+/ s m l}$ and $I r s 1^{s m l / s m l}$ cultures had significantly less pAKT compared with the $\operatorname{Irs} 1^{+/+}$control cultures (Fig. 1B). Upon stimulation with IGF1 or insulin, tAKT protein was the same across the genotypes, but the $\operatorname{Irs} 1^{+/+}$cultures showed higher levels of AKT phosphorylation than the $\operatorname{Irs} 1^{\text {sml/sml }}$ and the $\operatorname{Irs} 1^{+/ s m l}$ cells. Finally, we examined the amount of IRS2 in calvarial osteoblasts from $\operatorname{Irs} 1^{+/+}, \operatorname{Irs} 1^{+/ s m l}$, and $\operatorname{Irs} 1^{\mathrm{sml} / \mathrm{sml}}$ mice. Although total protein was the same for all the three genotypes, both $\operatorname{Irs} 1^{s m l / s m l}$ and $\operatorname{Irs} 1^{+/ s m l}$ calvarial osteoblasts showed enhanced phosphorylation of IRS-2 in response to IGF1 but not to insulin (Fig. 4) compared with the $\operatorname{Irs} 1^{+/+}$osteoblasts.

\section{Serum analysis}

Circulating levels of insulin and IGF1 were analyzed under fasting conditions. Irs $1^{\mathrm{sml} / \mathrm{sml}}$ mice were found to be relatively hyperinsulinemic, with 3.5- to 4-fold higher insulin levels compared with the $I r s 1^{+/+}$controls. Notably, heterozygous $\operatorname{Irs} 1^{+/ s m l}$ mice of both genders exhibit an intermediate phenotype marked by significantly higher serum levels of insulin compared with the Irs $1^{+/+}$controls, but lower insulin levels compared with the $\operatorname{Irs} 1^{\mathrm{sml} / \mathrm{sml}}$ mice (Fig. 5A). Serum IGF1 levels were modestly, but significantly reduced in the $\operatorname{Irs} 1^{\mathrm{sml} / \mathrm{sml}}$ mice relative to the controls. In addition, a gender effect was observed in the serum IGF1 levels such that the heterozygous $\operatorname{Irs} 1^{+/ s m l}$ and Irs $1^{\text {sml/sml }}$ serum IGF1 levels were significantly lower in the females than in the males of the same genotype $(P<0 \cdot 0005)$. Unexpectedly, there was no intermediate phenotype for the Irs $1^{+/ s m l}$ males. However, in the female $\operatorname{Irs} 1^{+/ s m l}$ mice, we observed the same intermediate phenotype for serum IGF1 seen in the previous phenotypic datasets (Fig. 5B).

\section{GTT and ITT}

To investigate whether the mild hyperinsulinemia in $\operatorname{Irs} 1^{\mathrm{sml} / \mathrm{sml}}$ mice was indicative of a pre-diabetic state, GTTs were performed on fasted Irs $1^{+/+}$, Irs $1^{+/ s m l}$, and $\operatorname{Irs} 1^{\text {sml/sml }}$ males and females at 8 weeks of age (Fig. 5C and D). At baseline, $\operatorname{Irs} 1^{s m l / s m l}$ mice exhibited significantly lower (30-40\%) fasting glucose levels compared with the controls (Fig. 5C). When challenged with glucose, $\operatorname{Ir} 1^{\text {sml/sml }}$ glucose values rose as expected, but remained significantly lower than either Irs $1^{+/+}$or $\operatorname{Irs} 1^{+/ s m l}$ levels throughout the study. Although baseline glucose levels differed, glucose levels peaked $20 \mathrm{~min}$ post injection in Irs $1^{\mathrm{sml} / \mathrm{sml}}$ mice, as in both $\operatorname{Irs} 1^{+/+}$or $\operatorname{Irs} 1^{+/ s m l}$ mice, and the rate of glucose metabolism was similar among all the three genotypes of mice.

For the ITT under non-fasting conditions, the $\operatorname{Irs} 1^{\mathrm{sml} / \mathrm{sml}}$ glucose levels decreased, but not to the full extent as seen in
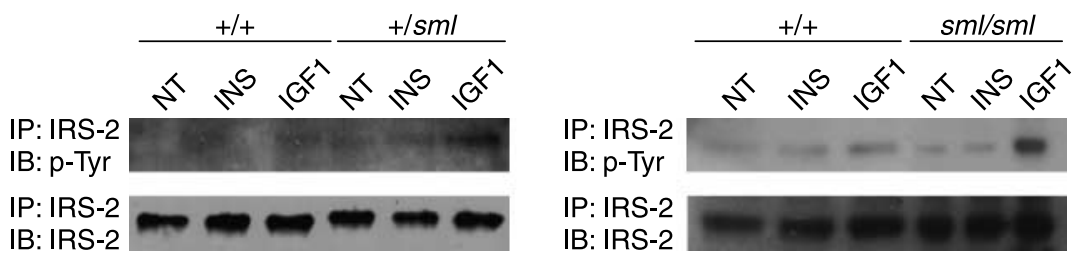

Figure 4 Mouse calvarial osteoblast cultures from $\operatorname{Irs} 1^{\mathrm{sml} / \mathrm{sml} /}, \operatorname{Irs} 1^{+/ \mathrm{sml} l}$, and $\operatorname{Irs} 1^{+/+}$mice were treated with IGF1 (IGF1) and insulin (INS) or were given no treatment (NT), harvested, and lysed as described in the Materials and Methods. Lysates were immunoprecipitated with an IRS-2 antibody and were then immunoblotted with IRS-2 for total protein levels or p-Tyr for phosphorylation of IRS-2. 

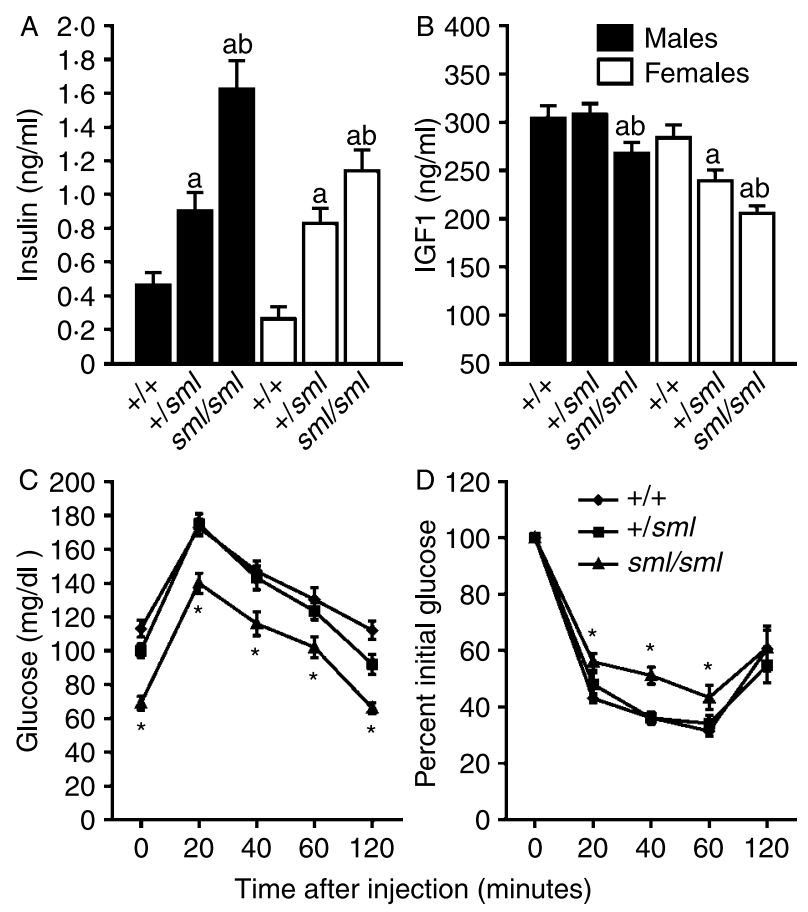

Figure 5 Fasted serum insulin and IGF1 levels and the glucose/ insulin tolerance tests of $I r s 1^{\mathrm{sml} / \mathrm{sml}}, \operatorname{Irs} 1^{+/ \mathrm{sml} l}$, and $I r s 1^{+/+}$fasted mice during the glucose and insulin tolerance tests. At 16 weeks of age, males and females were tested for (A) insulin and (B) IGF1 serum levels $\left(n=10\right.$ per genotype ${ }^{*} P \leq 0 \cdot 05 \operatorname{Irs} 1^{+/ s m l}$ versus $\operatorname{Irs} 1^{+/+}$, ${ }^{* *} P \leq 0.05 \mathrm{Irs} 1^{\mathrm{Sml}^{\mathrm{sm}} \mathrm{sml}}$ versus $\operatorname{Irs} 1^{+/+}$, and ${ }^{* * *} P \leq 0.05 \mathrm{Irs} 1^{\mathrm{sml} / \mathrm{sml}}$ versus $\left.I r s 1^{+/ s m l}\right)$. Male $I r s 1^{+/+}, \operatorname{Irs} 1^{+/ s m l}$, and $I r s 1^{\mathrm{sml} / \mathrm{sml}}$ mice at 8 weeks of age were fasted overnight and then subjected to a (C) GTT or fed ad libitum and then subjected to a (D) ITT as described in the Materials and Methods. Females were tested at the same time and they showed a similar pattern of significance $(n=10$ per genotype $\left.{ }^{*} P \leq 0 \cdot 05\right)$.

either Irs $1^{+/+}$or Irs $1^{+/ s m l}$ mice. The glucose-lowering effect of insulin, as assessed by an ITT (Fig. 5D), revealed a mild insulin insensitivity, which was depicted as a slight, but significant, upward shift in the curve for $\operatorname{Irs} 1^{\mathrm{sml} / \mathrm{sml}}$ mice, relative to either Irs $1^{+/+}$or Irs $1^{+/ s m l}$ mice (at 20-, 40-, and 60-min intervals). By $2 \mathrm{~h}$ post injection of insulin, Irs $1^{\mathrm{sml} / \mathrm{sm} l}$ glucose levels were comparable to those of the $\operatorname{Irs} 1^{+/+}$and Irs $1^{+/ s m l}$ mice.

\section{Discussion}

In this study, we have characterized for the first time a spontaneous mutation in the Irs 1 gene that results in a pronounced metabolic and skeletal phenotype. The $\operatorname{Irs} 1^{\text {sml }}$ mutation is a spontaneous frameshift mutation that results from a single nucleotide deletion in the Irs 1 gene leading to a premature stop codon and a truncated protein. This results in a hyperinsulinemic, lean, small mouse with reductions in serum IGF1 levels, BMD, and hearing. Mutant mice, although hyperinsulinemic, were only mildly insulin resistant as exogenous insulin treatment was effective in reducing circulating glucose levels. This partial ability of Irs $1^{\mathrm{sml} / \mathrm{sml}}$ mice to respond to exogenous insulin most likely prevents the development of overt hyperglycemia or diabetes.

The skeletal phenotype of the Irs $1^{\text {sml } / \text { sml }}$ mice is remarkable and differs from that of the genetically engineered Irs 1 null mice. Irs $1^{s m l / s m l}$ bones exhibited reductions in femur length, cortical and trabecular thicknesses, and trabecular number. In addition, Irs $1^{s m l / s m l}$ mice had a pronounced reduction in MAR and BFRs. But unexpectedly, these mutants had more osteoclasts and more osteoblasts per bone perimeter than the controls. To understand the mechanism for this surprising finding, we performed in vitro studies which demonstrated that Irs $1^{s m l / s m l}$ osteoblasts had impaired cell proliferation and differentiation, but no differences were found in osteoclast recruitment, differentiation, or appearance. Histological sections demonstrated that there was adequate recruitment of osteoblast precursors; hence the defect in bone formation was likely a result of poor osteoblast function due to reduced IRS-1 signaling. Taken together, we postulate that the markedly reduced bone volume fraction in the $\operatorname{Irs} 1^{\mathrm{sml} / \mathrm{sml}}$ mice is due to the inability of osteoblasts to form new bone coupled to an increase in osteoclastic activity, as evident by the larger eroded surfaces and the greater number of osteoclasts in the $\operatorname{Irs} 1^{s m l / s m l}$ mice. The absence of an in vitro effect on osteoclast differentiation from this mutation (see Fig. 3B) suggests that the osteoclastic changes are due to a non-cell autonomous process. In preliminary studies using real-time PCR on femoral and calvarial samples, we were unable to detect differences in gene expression for $R A N K L$, but we did find slightly lower Opg mRNA in the Irs $1^{\text {sml } / \text { sml }}$ bones versus Irs $1^{+/+}$controls. Whether the enhanced osteoblast recruitment is a compensatory response to a major defect in differentiative osteoblast function or another process remains to be determined. But, interestingly, Zhang et al. (2002) reported that mice with a conditional Igf1r deletion in osteoblasts exhibited defective mineralization, and had markedly increased osteoblast numbers. This would imply there must be feedback signals that operate during terminal differentiation that attempt to compensate for impaired skeletal function.

Similarities and differences exist between this spontaneous mutation and two genetically engineered mice, $\operatorname{Irs} 1^{\text {tm } 1 \text { Tka }}$ and Irs $1^{\text {tm } 1 J o s}$ with knockout alleles. For example, much like the Irs $1^{\text {sml }}$ mutation, the Irs $1^{\text {tm } 1 \text { Tka }}$ and Irs $1^{\text {tm } 1 J o s}$ null mutations result in small, lean, hyperinsulinemic mice, while the Irs $1^{\text {tm } 1 \text { Tka }}$ mice have reduced aBMD. Differences in phenotypes between the spontaneous $\operatorname{Irs} 1^{\mathrm{sml} / \mathrm{sml}}$ and the engineered Irs $1^{\text {tm 1Tka/tm1Tka }}$ and Irs $1^{\text {tm } 1 \text { Jos/tm 1Jos }}$ null mice include the lack of gender and heterozygous effects, as well as the degree of insulin resistance. Comparison of the spontaneous mutant to the Irs $1^{\text {tm } 1 \text { Tka }}$ allele also revealed differences in osteoblast and osteoclast numbers in vivo versus $+/+$ controls (Araki et al. 1994, Tamemoto et al. 1994, Ogata et al. 2000).

Phenotypic differences between the $\operatorname{Irs} 1^{\text {tm1Tka/tm1Tka, }}$ $\operatorname{Irs} 1^{\text {tm1Jos/tm IJos }}$, and the $\operatorname{Irs} 1^{\text {sml/sml }}$ mice may be the result of 
the different background strains. Reports have alluded to the importance of genetic background-contributing alleles that alter bone and growth phenotypes in mutants (Gonzalez et al. 1992, Bouxsein et al. 2002, Martelli et al. 2005). The genetically engineered Irs 1 null models are reported to be on a hybrid B6/CBA background strain, whereas the $\operatorname{Irs} 1^{\text {sml }}$ spontaneous mutation is on an inbred C3.SWR- $H 2^{b} / \mathrm{SnJ}$ congenic strain, which contains $\mathrm{C} 3 \mathrm{H}$ alleles at all genetic regions except for a small fixed region on chromosome 17 carrying the H2 allele. Thus, this background is more uniform compared with the segregating B6/CBA hybrid background. Modifier alleles within either background may account for the phenotypic variations observed between nulls and the spontaneous mutation.

Gender effects were not mentioned in the initial studies of the Irs $1^{\text {tm1Tka/tm1Tka }}$ and the Irs $1^{\text {tm 1 Jos/tm1Jos }}$ mice. Further characterization of the $\operatorname{Irs} 1^{\text {tm1Tka/tm1Tka }}$ mice reported no apparent differences by gender in serum IGF1 levels or in skeletal phenotyping (Ogata et al. 2000). However, phenotypic characterization of the Irs $1^{\text {sml }}$ mutation revealed gender differences for circulating IGF1, microarchitectural characteristics of bone, and osteoblast and osteoclast numbers by histomorphometry. In fact, Irs $1^{\text {tm1Tka/tm1Tka }}$ males are reported to have decreased numbers of both osteoblasts and osteoclasts (Hoshi et al. 2004, Yamaguchi et al. 2005), while the $\operatorname{Irs} 1^{\text {sml/sml }}$ male mice had normal numbers of both, and $\operatorname{Irs} 1^{\text {sml/sml }}$ female mice actually had more osteoblasts and osteoclasts. The gender effects are likely to be complex, but they may be a consequence of interactions involving estrogen, IGF1 signaling, and bone turnover.

Ogata et al. (2000) reported no phenotypic differences between the heterozygous and $+/+$ controls in the Irs $1^{\text {tm1Tka/tm1Tka }}$ nulls. The Irs $1^{+/ s m l}$ mice on the other hand exhibited a heterozygous phenotype for body weight, serum insulin, IGF1, femur length, aBMD and vBMD, and body fat. Moreover, the Irs $1^{+/ s m l}$ calvarial osteoblasts had some impairment in the phosphorylation of AKT that could explain the phenotypic changes. Furthermore, closer examination of bone microstructure revealed a heterozygous phenotype for the cortical compartment, such that the Irs $1^{+/ s m l}$ mice exhibited an intermediate phenotype for cortical thickness and periosteal circumference, but not for the trabecular compartment for bone volume fraction (See Table 2). On dynamic histomorphometry, the $\operatorname{Irs} 1^{+/ s m l}$ mice also had increased numbers of osteoclasts and reduced MAR compared with the controls (see Supplementary Table S1), suggesting that the heterozygote mice truly exhibit an intermediate phenotype for several components of skeletal turnover. It is interesting to speculate as to why the cortical component but not the trabecular component of the skeleton is affected by gene dosing. One possibility is that the increase in resorption in the heterozygotes is not as dramatic as that in the mutants, and this combined with minimal alterations in BFRs results in barely detectable changes in the trabecular bone volume fraction of Irs $1^{+/ s m l}$ mice. In contrast, despite body composition change in the $I r s 1^{+/ s m l}$ mice, there was no intermediate metabolic phenotype when the mice were challenged with glucose or insulin. Although no heterozygous phenotype was reported for the bones of $\operatorname{Irs} 1^{\text {tm1Tkal }}$ ${ }^{\text {tm } 1 \text { Tka }}$ mice, a study done by Pete et al. (1999) did report small but significant reductions in body and organ weight in heterozygous Irs $1^{+/ \operatorname{tm} 1 \text { Jos }}$ mice. Once again, it is likely that these strain differences could be related to the background of the mice and/or any compensatory effect of IRS-2 (see Fig. 4) that might result from the loss of a single allele in the Irs 1 gene.

Numerous studies have provided evidence of hyperinsulinemia, impaired glucose tolerance, and insulin resistance in Irs1 null mice (Araki et al. 1994, Tamemoto et al. 1994, Yamauchi et al. 1996, Kido et al. 2000). Initial studies on both

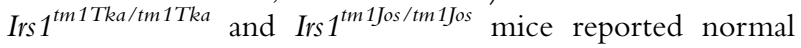
physiological glucose levels after fasting conditions. However,

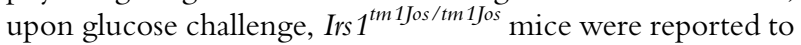
be somewhat glucose intolerant as their circulating glucose levels significantly increased compared with the $+/+$ controls, whereas the Irs $1^{\text {tm1Tka/tm1Tka }}$ mice were reported to have no differences compared with the $+/+$ controls.

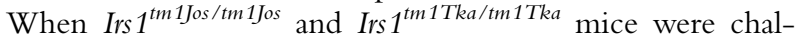
lenged with insulin, significantly increased levels of glucose were observed again in both the groups compared with the controls, indicating insulin resistance. The $\operatorname{Irs} 1^{\mathrm{sml} / \mathrm{sml}}$ mice, on the other hand, exhibited a compensatory hyperinsulinemia due to the lack of IRS1, but retained some insulin sensitivity, as shown by their nearly intact response to the glucoselowering effects of exogenous insulin. Furthermore, the $\operatorname{Irs} 1^{\text {sml/sml }}$ mice exhibited one-third lower glucose levels after fasting and throughout the GTT. This attenuated glucose response can be explained by the moderate hyperinsulinemia found in $\operatorname{Irs} 1^{\mathrm{sml} / \mathrm{sml}}$ mice.

Initial characterizations of the $\operatorname{Irs} 1^{\mathrm{tm} 1 \mathrm{Tka} / \mathrm{tm} 1 \mathrm{Tka}}$ mice reported no significant differences in serum IGF1 levels (Tamemoto et al. 1994). However, Pete et al. (1999) reported a decrease in IGF1 levels in Irs $1^{\text {tm1Jos/tm1Jos mice compared }}$ with the controls, but the change did not reach significance, most likely due to low sampling numbers. In the spontaneous $\operatorname{Irs} 1^{\text {sml/sml }}$ mice, there was a consistent $20 \%$ decrease in IGF1 levels compared with the Irs $1^{+/+}$control mice. Dong et al. (2006) also reported a $20 \%$ decrease in IGF1 levels in the Irs $1^{\text {tm } 1 \mathrm{Jos} / \mathrm{tm} 1 \mathrm{Jos}}$ mouse compared with the controls. The $20 \%$ reduction in the IGF1 serum levels in the $\operatorname{Irs} 1^{\mathrm{sml} / \mathrm{sml}}$ mice is an unexpected observation. A defect in signaling should result in increased IGF1 levels rather than in a decrease, presumably as a compensatory mechanism. It is probable that the overexpression of IGF1 could partially compensate for the lack of IRS1 in postnatal growth (Pete et al. 1999). However, we postulate the emergence of a negative feedback loop in the absence of IRS1 that leads to reduced IGF1 synthesis. How that inhibition occurs (perhaps locally by alterations in $\mathrm{GH}$ signaling) is a subject of further investigations.

We assume that the Irs $1^{\text {sml }}$ mutation results in complete loss of function, but cannot rule out the possibility of a hypomorphic mutation. Indeed, it is possible that a 
211-amino acid truncated peptide is produced and may bind to the IGF1 receptor by its phosphotyrosine-binding (PTB) domain. If so, all the sites of binding and phosphorylation downstream of the PTB domain are missing resulting in defective signaling as evidenced by the lack of AKT phosphorylation in mouse calvarial osteoblast cells when stimulated with IGF1 or insulin. This deleted region includes serine residues, which when phosphorylated, trigger protein degradation. Thus, it is possible that the truncated peptide may attach to the IGF1 receptor and perturb the system, resulting in the phenotypic differences observed between our spontaneous mutant and the engineered mutants of the Irs 1 gene. Repeated attempts to use the only commercially available N-terminus-specific antibody were unsuccessful. However, since the PTB domain of the IRS1 protein comprises residues 144-316, our predicted protein would contain $<50 \%$ of the PTB domain, and thus binding to the receptor is unlikely.

Reduced circulating IGF1 and mutations in the Igf1 gene have been directly linked to hearing loss in both mice and humans (Woods et al. 1996, Camarero et al. 2001, Barrenäs et al. 2003, Bonapace et al. 2003, Cediel et al. 2006). Mice lacking the Igf1 gene have been shown to lose many auditory neurons and exhibit increased auditory thresholds indicative of hearing impairment (Camarero et al. 2001, Cediel et al. 2006). It has also been shown that IGF1 is critical in the development of the cochleovestibular ganglion in the inner ear (Varela-Nieto et al. 2004). Furthermore, lack of IGF1, or mutations in the IGF1 gene, has been associated with sensorineural hearing loss in humans (Woods et al. 1996, Bonapace et al. 2003). Thus, the fact that Irs $1^{\text {sml }}$ mice exhibit hearing loss further supports the existence of a major defect in the IGF1 signaling pathway.

Recently, a SNP located adjacent to the Irs 1 gene has been associated with type 2 diabetes, insulin resistance, and hyperinsulinemia in a human cohort of more than 14000 individuals. The investigators reported a $40 \%$ reduction in the basal levels and function of IRS1 protein in the skeletal muscle of patients carrying this variant (Rung et al. 2009). Likewise, there are numerous studies on humans demonstrating polymorphisms in the Irs 1 gene associated with variable responsiveness to insulin signaling (Imai et al. 1994, Ura et al. 1996, Le Fur et al. 2002). The most common polymorphism, the G972R variant, has also been associated with type II diabetes mellitus (Almind et al. 1993, Sesti 2000, Tok et al. 2006). However, there are no data examining the relationship between these polymorphisms and BMD or fracture risk. Based on our work combined with previous studies performed on the Irs 1 knockout models, we predict that patients with IRS1 polymorphisms could have a subclinical but important skeletal phenotype.

There are several limitations of our studies. First, the mechanism responsible for the low serum IGF1 levels in the Irs $1^{\text {sml } / s m l}$ mice is not readily apparent from our data. Secondly, the degree of compensation between IRS1 and IRS2 in the mutant and heterozygote models requires further study.
Thirdly, the hyperinsulinemia along with the mild insulin resistance phenotype is intriguing and raises new questions about the importance of IRS1 in glucose homeostasis. Fourthly, the heterozygous phenotype is particularly provocative as it lends credence to the theory that similar mutations in the Irs 1 gene may exist in humans. These are likely to be characterized by relatively modest reductions of IGF1, low fat mass, hyperinsulinemia, reduced BMD, and short stature. However, this theory will need to be verified in large population studies. Finally, the increase in osteoclastogenesis in both the mutant and heterozygote mice requires further study to determine if the relatively modest reduction in Opg mRNA in the pre-osteoblasts of these mice is partly responsible for the skeletal phenotype. Notwithstanding, this paper reports the first spontaneous 'loss of function' mutation in the Irs 1 gene. The unique phenotypic presentation of this mutant raises new questions about the role of IRS1 in both skeletal acquisition and glucose homeostasis.

\section{Supplementary data}

This is linked to the online version of the paper at http://dx.doi.org/10.1677/ JOE-09-0328.

\section{Declaration of interest}

The authors declare that there is no conflict of interest that could be perceived as prejudicing the impartiality of the research reported.

\section{Funding}

This work was supported by the National Institute of Heath (grants: RR01183, ARMYLRD, DK042424, DK073267, AR46544, and AR043618).

\section{Acknowledgements}

The authors would like to thank Lindsay G Horton, Colleen Kane, Belinda Harris, Leona Gagnon, Krista Delahunty, Lisa Carney, Pat Ward-Bailey, and Cheryl Ackert-Bicknell for assistance with this research.

\section{References}

Almind K, Bjørbaek C, Vestergaard H, Hansen T, Echwald S \& Pedersen O 1993 Aminoacid polymorphisms of insulin receptor substrate-1 in non-insulin-dependent diabetes mellitus. Lancet 342 828-832.

Araki E, Lipes MA, Patti ME, Brüning JC, Haag B, Johnson RS \& Kahn CR 1994 Alternative pathway of insulin signalling in mice with targeted disruption of the IRS-1 gene. Nature 10 186-190.

Atti E, Boskey AL \& Canalis E 2005 Overexpression of IGF-binding protein 5 alters mineral and matrix properties in mouse femora: an infrared imaging study. Calcified Tissue International 76 187-193.

Barrenäs ML, Bratthall A \& Dahlgren J 2003 The thrifty phenotype hypothesis and hearing problems. BMJ 327 1199-2000.

Baumann G 1999 Mutations in the growth hormone releasing hormone receptor: a new form of dwarfism in humans. Growth Hormone and IGF Research 9 24-29. 
Beamer WG, Shultz KL, Ackert-Bicknell CL, Horton LG, Delahunty KM, Coombs HF III, Donahue LR, Canalis E \& Rosen CJ 2007 Genetic dissection of mouse distal chromosome 1 reveals three linked BMD QTLs with sex-dependent regulation of bone phenotypes. Journal of Bone and Mineral Research 22 1187-1196.

Ben Lagha N, Seurin D, Le Bouc Y, Binoux M, Berdal A, Menuelle P \& Babajko S 2006 Insulin-like growth factor binding protein (IGFBP-1) involvement in intrauterine growth retardation: study on IGFBP-1 overexpressing transgenic mice. Endocrinology 147 4730-4737.

Bikle D, Majumdar S, Laib A, Powell-Braxton L, Rosen C, Beamer W, Nauman E, Leary C \& Halloran B 2001 The skeletal structure of insulin-like growth factor I-deficient mice. Journal of Bone and Mineral Research 16 2320-2329.

Bonapace G, Concolino D, Formicola S \& Strisciuglio P 2003 A novel mutation in a patient with insulin-like growth factor 1 (IGF1) deficiency. Journal of Medical Genetics 40 913-917.

Bouxsein ML, Rosen CJ, Turner CH, Ackert LC, Shultz KL, Donahue LR, Churchill GA, Adamo ML, Powell DR, Turner RT et al. 2002 Generation of a new congenic mouse strain to test the relationships among serum insulin-like growth factor I, bone mineral density, and skeletal morphology in vivo. Journal of Bone and Mineral Research 17 570-579.

Camarero G, Avendano C, Fernandez-Moreno C, Villar A, Contreras J, de Pablo F, Pichel JG \& Varela-Nieto I 2001 Delayed inner ear maturation and neuronal loss in postnatal Igf-1 deficient mice. Journal of Neuroscience 21 7630-7641.

Cediel R, Riquelme R, Contreras J, Díaz A \& Varela-Nieto I 2006 Sensorineural hearing loss in insulin-like growth factor I-null mice: a new model of human deafness. European Journal of Neuroscience 23 587-590.

Cornish J, Callon KE \& Reid IR 1996 Insulin increases histomorphometric indices of bone formation in vivo. Calcified Tissue International 59 492-495.

Delahunty KM, Shultz KL, Gronowicz GA, Koczon-Jaremko B, Adamo ML, Horton LG, Lorenzo J, Donahue LR, Ackert-Bicknell CL, Kream BE et al. 2006 Congenic mice provide in vivo evidence for a genetic locus that modulates serum insulin-like growth factor-1 and bone acquisition. Endocrinology 147 3915-3923.

DeMambro VE, Clemmons DR, Horton LG, Bouxsein ML, Wood TL, Beamer WG, Canalis E \& Rosen CJ 2008 Gender-specific changes in bone turnover and skeletal architecture in igfbp-2-null mice. Endocrinology 149 2051-2061

Donahue LR \& Beamer WG 1993 Growth hormone deficiency in 'little' mice results in aberrant body composition, reduced insulin-like growth factor-I and insulin-like growth factor-binding protein-3 (IGFBP-3), but does not affect IGFBP-2, -1 or -4. Journal of Endocrinology 136 91-104.

Dong X, Park S, Lin X, Copps K, Yi X \& White MF 2006 Irs1 and Irs2 signaling is essential for hepatic glucose homeostasis and systemic growth. Journal of Clinical Investigation 116 101-114.

Gagnon LH, Longo-Guess CM, Berryman M, Shin JB, Saylor KW, Yu H, Gillespie PG \& Johnson KR 2006 The chloride intracellular channel protein CLIC5 is expressed at high levels in hair cell stereocilia and is essential for normal inner ear function. Journal of Neuroscience $\mathbf{2 6}$ 10188-10198.

Garnero P, Sornay-Rendu E \& Delmas PD 2000 Low serum IGF-1 and occurrence of osteoporotic fractures in postmenopausal women. Lancet 355 898-899.

Giustina A, Mazziotti G \& Canalis E 2008 Growth hormone, insulin-like growth factors, and the skeleton. Endocrine Reviews 29 535-559.

Godfrey P, Rahal JO, Beamer WG, Copeland NG, Jenkins NA \& Mayo KE 1993 GHRH receptor of little mice contains a missense mutation in the extracellular domain that disrupts receptor function. Nature Genetics $\mathbf{4}$ 227-232.

Gonzalez CD, Meyer RAJ \& Iorio RJ 1992 Craniometric measurements of craniofacial malformations in the X-linked hypophosphatemic (Нyp) mouse on two different genetic backgrounds: $\mathrm{C} 57 \mathrm{BL} / 6 \mathrm{~J}$ and $\mathrm{B} 6 \mathrm{C} 3 \mathrm{H}$ Teratology 46 605-613.

He J, Rosen CJ, Adams DJ \& Kream BE 2006 Postnatal growth and bone mass in mice with IGF-I haploinsufficiency. Bone 38 826-835.
Hoshi K, Ogata N, Shimoaka T, Terauchi Y, Kadowaki T, Kenmotsu S, Chung UI, Ozawa H, Nakamura K \& Kawaguchi H 2004 Deficiency of insulin receptor substrate-1 impairs skeletal growth through early closure of epiphyseal cartilage. Journal of Bone and Mineral Research 19 214-223.

Imai Y, Fusco A, Suzuki Y, Lesniak MA, D'Alfonso R, Sesti G, Bertoli A, Lauro R, Accili D \& Taylor SI 1994 Variant sequences of insulin receptor substrate-1 in patients with noninsulin-dependent diabetes mellitus. Journal of Clinical Endocrinology and Metabolism 79 1655-1658.

Janghorbani M, Feskanich D, Willett WC \& Hu F 2006 Prospective study of diabetes and risk of hip fracture: the Nurses' Health Study. Diabetes Care 29 1573-1578.

Janghorbani M, Van Dam RM, Willett WC \& Hu FB 2007 Systematic review of type 1 and type 2 diabetes mellitus and risk of fracture. American Journal of Epidemiology 166 495-505.

Kido Y, Burks DJ, Withers D, Bruning JC, Kahn CR, White MF \& Accili D 2000 Tissue-specific insulin resistance in mice with mutations in the insulin receptor, IRS-1, and IRS-2. Journal of Clinical Investigation 105 199-205.

Le Fur S, Le StunffC \& Bougnères P 2002 Increased insulin resistance in obese children who have both 972 IRS-1 and 1057 IRS-2 polymorphisms. Diabetes 51 S304-S307.

Lienhard GE 1994 Insulin. Life without the IRS. Nature 372 128-129.

Liu JP, Baker J, Perkins AS, Robertson EJ \& Efstratiadis A 1993 Mice carrying null mutations of the genes encoding insulin-like growth factor I (Igf-1) and type 1 IGF receptor (Igf1r). Cell 75 59-72.

Maheshwari HG, Silverman BL, Dupuis J \& Baumann G 1998 Phenotype and genetic analysis of a syndrome caused by an inactivating mutation in the growth hormone-releasing hormone receptor: dwarfism of Sindh. Journal of Clinical Endocrinology and Metabolism 88 4065-4074.

Manly KF, Cudmore RHJ \& Meer JM 2001 Map Manager QTX, crossplatform software for genetic mapping. Mammalian Genome 12 930-932.

Martelli F, Ghinassi B, Panetta B, Alfani E, Gatta V, Pancrazzi A, Bogani C, Vannucchi AM, Paoletti F, Migliaccio G et al. 2005 Variegation of the phenotype induced by the Gatallow mutation in mice of different genetic backgrounds. Blood 106 4102-4113.

Messier C \& Kent P 1995 Repeated blood glucose measures using a novel portable glucose meter. Physiology \& Behavior 57 807-811.

Mukherjee A, Murray RD \& Shalet SM 2004 Impact of growth hormone status on body composition and the skeleton. Hormone Research 62 35-41.

Niu T \& Rosen CJ 2005 The insulin-like growth factor-I gene and osteoporosis: a critical appraisal. Gene 361 38-56.

Ogata N, Chikazu D, Kubota N, Terauchi Y, Tobe K, Azuma Y, Ohta T, Kadowaki T, Nakamura K \& Kawaguchi H 2000 Insulin receptor substrate-1 in osteoblast is indispensable for maintaing bone turnover Journal of Clinical Investigation 105 935-943.

Parfitt AM, Drezner MK, Glorieux FH, Kanis JA, Malluche H, Meunier PJ, Ott SM \& Reckner RR 1987 Bone histomorphometry: standardization of nomenclature, symbols and units. Report of the ASBMR nomenclature committee. Journal of Bone and Mineral Research 2 595-610.

Pete G, Fuller CR, Oldham JM, Smith DR, D'Ercole AJ, Kahn CR \& Lund PK 1999 Postnatal growth responses to insulin-like growth factor I in insulin receptor substrate-1-deficient mice. Endocrinology 140 5478-5487.

Räkel A, Sheehy O, Rahme E \& LeLorier J 2008 Osteoporosis among patients with type 1 and type 2 diabetes. Diabetes \& Metabolism 34 193-205.

Rosen C, Churchill G, Donahue L, Shultz K, Burgess J, Powell D \& Beamer W 2000 Mapping quantitative trait loci for serum insulin-like growth factor-1 levels in mice. Bone 27 521-528.

Rosen CJ, Ackert-Bicknell CL, Adamo ML, Shultz KL, Rubin J, Donahue LR, Horton LG, Delahunty KM, Beamer WG, Sipos J et al. 2004 Congenic mice with low serum IGF-1 have increased body fat, reduced bone mineral density, and an altered osteoblast differentiation program. Bone 35 1046-1058.

Rung J, Cauchi S, Albrechtsen A, Shen L, Rocheleau G, Cavalcanti-Proença C, Bacot F, Balkau B, Belisle A, Borch-Johnsen K et al. 2009 Genetic variant near IRS1 is associated with type 2 diabetes, insulin resistance and hyperinsulinemia. Nature Genetics 41 1110-1115.

Sesti G 2000 Insulin receptor substrate polymorphisms and type 2 diabetes mellitus. Pharmacogenetics 1 343-357. 
Shimoaka T, Kamekura S, Chikuda H, Hoshi K, Chung UI, Akune T, Maruyama Z, Komori T, Matsumoto M, Ogawa W et al. 2004 Impairment of bone healing by insulin receptor substrate-1 deficiency. Journal of Biological Chemistry 279 15314-15322.

Shirakami A, Toyonaga T, Tsuruzoe K, Shirotani T, Matsumoto K, Yoshizato K, Kawashima J, Hirashima Y, Miyamura N, Kahn CR et al. 2002 Heterozygous knockout of the IRS-1 gene in mice enhances obesity-linked insulin resistance: a possible model for the development of type 2 diabetes. Journal of Endocrinology 174 309-319.

Silha JV, Mishra S, Rosen CJ, Beamer WG, Turner RT, Powell DR \& Murphy LJ 2003 Perturbations in bone formation and resorption in insulin-like growth factor binding protein-3 transgenic mice. Journal of Bone and Mineral Research 18 1834-1841.

Tamemoto H, Kadowaki T, Tobe K, Yagi T, Sakura H, Hayakawa T, Terauchi Y, Ueki K, Kaburagi Y, Satoh S et al. 1994 Insulin resistance and growth retardation in mice lacking insulin receptor substrate-1. Nature 372 182-186.

Tok EC, Ertunc D, Bilgin O, Erdal EM, Kaplanoglu M \& Dilek S 2006 Association of insulin receptor substrate-1 G972R variant with baseline characteristics of the patients with gestational diabetes mellitus. American Journal of Obstetrics and Gynecology 194 868-872.

Ura S, Araki E, Kishikawa H, Shirotani T, Todaka M, Isami S, Shimoda S, Yoshimura R, Matsuda K, Motoyoshi S et al. 1996 Molecular scanning of the insulin receptor substrate-1 (IRS-1) gene in Japanese patients with NIDDM: identification of five novel polymorphisms. Diabetologia 39 600-608.

Varela-Nieto I, Morales-Garcia JA, Vigil P, Diaz-Casares A, Gorospe I, Sánchez-Galiano S, Cañon S, Camarero G, Contreras J, Cediel R et al. 2004 Trophic effects of insulin-like growth factor-I (IGF-I) in the inner ear. Hearing Research 196 19-25.

Vestergaard P, Jørgensen JO, Hagen C, Hoeck HC, Laurberg P, Rejnmark L, Brixen K, Weeke J, Andersen M, Conceicao FL et al. 2002 Fracture risk is increased in patients with GH deficiency or untreated prolactinomas - a case-control study. Clinical Endocrinology 56 159-167.

Wang Y, Nishida S, Elalieh HZ, Long RK, Halloran BP \& Bikle DD 2006 Role of IGF-I signaling in regulating osteoclastogenesis. Journal of Bone and Mineral Research 21 1350-1358.

Weitgasser R, Gappmayer B \& Pichler M 1999 Newer portable glucose meters - analytical improvement compared with previous generation devices. Clinical Chemistry 45 1821-1825.
White MF 2003 Insulin signaling in health and disease. Science 302 1710-1711.

Woods KA, Camacho-Hübner C, Savage MO \& Clark AJ 1996 Intrauterine growth retardation and postnatal growth failure associated with deletion of the insulin-like growth factor I gene. New England Journal of Medicine 335 1363-1367.

Yakar S, Liu JL, Stannard B, Butler A, Accili D, Sauer B \& LeRoith D 1999 Normal growth and development in the absence of hepatic insulin-like growth factor I. PNAS 96 7324-7329.

Yakar S, Rosen CJ, Bouxsein ML, Sun H, Mejia W, Kawashima Y, Wu Y, Emerton K, Williams V, Jepsen K et al. 2009 Serum complexes of insulin-like growth factor-1 modulate skeletal integrity and carbohydrate metabolism. FASEB Journal 23 709-719.

Yamaguchi M, Ogata N, Shinoda Y, Akune T, Kamekura S, Terauchi Y, Kadowaki T, Hoshi K, Chung UI, Nakamura K et al. 2005 Insulin receptor substrate-1 is required for bone anabolic function of parathyroid hormone in mice. Endocrinology 146 2620-2628.

Yamauchi T, Tobe K, Tamemoto H, Ueki K, Kaburagi Y, Yamamoto-Honda R, Takahashi Y, Yoshizawa F, Aizawa S, Akanuma Y et al. 1996 Insulin signaling and insulin actions in the muscles and livers of insulin-resistant, insulin receptor substrate 1-deficient mice. Molecular and Cellular Biology 116 101-114.

Zhang M, Xuan S, Bouxsein ML, von Stechow D, Akeno N, Faugere MC, Malluche H, Zhao G, Rosen CJ, Efstratiadis A et al. 2002 Osteoblast-specific knockout of the insulin-like growth factor (IGF) receptor gene reveals an essential role of IGF signaling in bone matrix mineralization. Journal of Biological Chemistry 277 44005-44012.

Zhang M, Faugere MC, Malluche H, Rosen CJ, Chernausek SD \& Clemens TL 2003 Paracrine overexpression of IGFBP-4 in osteoblasts of transgenic mice decreases bone turnover and causes global growth retardation. Journal of Bone and Mineral Research 18 836-843.

\section{Received in final form 9 December 2009 Accepted 23 December 2009 Made available online as an Accepted Preprint 23 December 2009}

